\title{
Teachers' Perception of HOTS-Based Learning in EFL Classroom
}

\author{
Putu Ayu Laras Pradnyani Nirmala Giri \\ Universitas Pendidikan Ganesha, Indoensia \\ pradnyanilaras@gmail.com
}

\begin{abstract}
This study examines the perception of English teachers towards HOTS-based Learning in EFL classroom. This study was a survey study with interview as the data collection technique. The participants of the study were five English teachers in senior high school in Singaraja, Buleleng, Bali. The result of data analysis found that teachers' awareness of implementing HOTS-based instruction starting from lesson plan, teaching strategies that promote higher thinking and assessment. However, teachers also faced difficulties in developing HOTS-based Instructions such as limited knowledge and lack of training. It is suggested that English teachers broaden their knowledge on developing HOTS-based instruction and conduct a discussion with peers and experts. The role of principle is also essential in giving instructions and training towards HOTS-based learning instructions.
\end{abstract}

Keywords: English Teachers, HOTS, Instruction

\section{INTRODUCTION}

The significance of education in fostering people to be ready to face a global challenge attracts the government's attention considering that people are demanded to be able to compete in $21^{\text {st }}$ century era. People are required to master several skills called $21^{\text {st }}$ century skills. Tyas et al (2019) states that the development of $21^{\text {st }}$ century requires people to master $21^{\text {st }}$ century skills in order to face a global competition. It is also added that education is directly contributing to foster people's readiness and becomes a central attention. Meanwhile, the $21^{\text {st }}$ century skills are defined as the progressive skills that needs creativity, persistence, and problem solving combined with performance as a part of a team well (Duncan, 2009). Those skills have been included in Indonesian education through the implementation of HOTS or Higher Order Thinking Skills as regulated in the latest curriculum. It is known as curriculum 2013. Ahmad (2014) states that Indonesian national ministries of educational and culture applies the $21^{\text {st }}$ century skills in the classroom-learning context by implementing the 2013 curriculum which consists of several new education policies includes higher order thinking skills (HOTS) as the most crucial policy.

Kusumastuti et al (2019) point out that the ministry of education and culture divided into four basic skills required in $21^{\text {st }}$ century, such as; critical thinking, creative, collaborative, and communicative. Brookhart (2010) defines HOTS as a high level of cognitive activity which covers some abilities, such as; the ability of transferring new concepts in a new situation, defining a problem logically, solving the problem creatively, arguing critically, and making a conclusion. In addition, HOTS is not only categorized as an assessment item but it also covers as a learning method. Bahrudin et al (2020) states that higher order thinking skill (HOTS) contains of three authorities in the cognitive skills in which it is seen based 
on Blooms Taxonomy, they are; analysis, synthesis and evaluation. Blooms Taxonomy is considered as an instrument which helps the teacher until now.

HOTS as a learning method has been implemented in Indonesia through the emergence the 2013 curriculum. It is supported by Assaly and Smadi (2015) who argue that several countries have adapted higher order thinking skills (HOTS), one of them is Indonesia. The 2013 curriculum or also known as K.13 has an element used to strengthen the learning process which is believed that it can increase the learning quality to be more effective, efficient, steady, and meaningful. It is continued by Yee et al (2016) who emphasizes that students can develop their thinking quality through the assistance of higher-order thinking skills in which it also assists them to upgrade their skills and value or apply their knowledge when they have to solve a problem. However, teachers still faced difficulties in implementing HOTS-based learning. Warmadewi et al (2019) states that HOTS-Based learning has been introduced through the implementation of the 2013 curriculum but in the real life, many educators do not understand and cannot implement it. It occurs because the theories are transferred solely without a real example or practices which show the implementation of HOTS learning during the training. Another difficulty comes from the textbook provided by the government in supporting the implementation of HOTS. It is viewed from the integration of HOTS in English as Foreign Language (EFI) subject, as what Tyas et al (2019) say that it closely relates to several aspects, such as; national curriculum policy, textbook availability, teachers, and students' cognitive abilities. The national curriculum clearly requires the engagement of HOTS in the EFL teaching-learning process. The textbook provided by the government is not enough to encourage students' higher order thinking skill.

Looking at the explanation above, the current study intended to explore English teachers' perception towards HOTS-based instruction in EFL classroom. Besides that, this study also seeks the implementation of HOTS-based instruction in classroom and the challenges of implementing HOTS-based instruction.

\section{METHOD}

This study was a survey study. The survey was conducted through interview with five high school English teachers in Singaraja, Bali. The interview technique used was a semi structured interview. The data analysis technique used was interactive model analysis by Miles et al., (2014). The data analysis consists of four steps namely data collection, data display, data reduction, conclusion drawing.

\section{FINDINGS \& DISCUSSIONS}

After collecting and analyzing the data, there are four themes merged namely awareness of the importance of HOTS, strategies for implementing HOTS, limited knowledge and experience, and challenges of implementing HOTS.

\section{Awareness of the importance of HOTS-based Instructions}

Teachers are aware of the importance of implementing HOTS in learning. As revealed during the interview:

Yes, I think HOTS is very important in 21st century learning. Students are trained to think critically and creatively. (Teacher 1) 
HOTS learning has been emphasized in the 2013 curriculum. So, we as teachers are obliged to implement it in the classroom. (Teacher 2)

I agree with the implementation of HOTS in the classroom. It trains students to have 421 st century skills, namely communication, collaboration, critical thinking, and creativity. (Teacher 4)

Judging from the teacher's answers, the implementation of HOTS-based instruction is in accordance with the 2013 curriculum which is currently being implemented in Indonesia. They also saw that HOTS-based instruction trains $21 \mathrm{st}$ century students' skills of communication, collaboration, critical thinking, and creativity. This was in line with a study conducted by Ardini (2017) who found that teachers support the implementation of HOTS-based instruction in classroom. Another study conducted by Hashim et al., (2015) found that teachers need HOTS-based instruction in fostering innovation in classroom. Pulungan et al., (2021) also emphasize the importance of implementing HOTS-based instruction as early as possible. The implementation of HOTS-based instruction will have an impact on the learning process from being passive to being active adjusting with the demands of 21st century competence (Afifah \& Retnawati, 2019).

\section{The Implementation of HOTS-based Instruction}

The teachers claimed that they have implemented HOTS-based instruction in the classroom. They use several approaches such as project-based and problem-based learning. In the interview they said:

I use project-based learning to emphasize HOTS. Here I want to train students' ability to solve problems and work collaboratively. (Teacher 1)

I mostly use problem-based in HOTS. I give a problem to students, and ask them to solve the problem. This problembased helps student students to think critically and innovatively in solving problems and getting solutions. (Teacher 5)

Project based learning is defined as a learning model that leads students to solve a factual problem where it can be reached through systematic and measurable work stages. Project based learning also can improve students' ability to analyse, evaluate, and interpret in which it also increases students' creativity on the several dimensions, such as; resolution, elaboration, and novelty as well as aspects including fluency, authenticity, and flexibility (Tyas et al., 2019). Suherman et al., (2020) found that using project-based learning in classroom was effective in enhancing students' higher order thinking skill. They emphasized that project-Based Learning was very successful in building four pillars of learning and the students' problem-solving abilities.

The other technique used by teachers in implementing HOTS-based instruction was problem-based learning. Problem based-learning is considered as a learning model that shows a problematic situation which is authentic and meaningful for students and it can be used for conducting a study and investigation. It can be seen through the implementation of problem based learning done by Kurniawati (2019) on her study designed to investigate how 
problem based learning can improve students' higher order thinking skills in Introduction to microeconomics course.

\title{
3. Challenges in Using HOTS-based Instruction
}

From the interview results, there are teachers who admit that they have not implemented HOTS-based instruction. There are several difficulties faced by teachers in implementing HOTS as revealed in the interview:

\begin{abstract}
Honestly, I haven't used HOTS in class. I find it difficult to develop hots-based learning because of the lack of reading and asking other teachers. (Teacher 3 )
\end{abstract}

The difficulty is when developing a HOTS-based assessment for reading skills. Sometimes I get confused which one is categorized as high and low level. (Teacher 5)

It can be said that teachers still have difficulties in implementing HOTS. This difficulty is due to their lack of knowledge about HOTS. In addition, the teacher also revealed that he had difficulties in developing HOTS-based assessments, especially for reading skills. Afifah and Retnawati (2019) found that factors that influence difficulties in integrating HOTS in classroom is teachers' lack of knowledge thus the teachers cannot design and apply HOTS-based instruction. Similar findings were also identified in a study conducted by Ginting and Kuswandono (2020) who found that teachers do not understand the concept, definition and implementation of HOTS due to lack of knowledge. Kusumastuti et al (2019) adds that the involvement of HOTS in EFL classroom is also due to students' knowledge, ability, and motivation.

The successful implementation of HOTS does not only depend on how it is implemented in the classroom but it involves all the stakeholders. In order to increase and increase teacher knowledge about HOTS, training needs to be given to teachers. This was stressed by Seman et al., (2017) who stated that in order to enhance teachers' understanding towards HOTS, they needed an extensive training. Nachiappan et al., (2018) emphasized that in implementing HOTS, school principals also have an active role to always provide encouragement to teachers in developing and implementing HOTS-based instruction.

\section{CONCLUSIONS}

The current study investigated the perception of English teachers towards HOTS-based Learning in EFL classroom. It was found that the teachers are aware of the importance of integrating HOTS-based in classroom. They already implemented HOTS-based instruction using project-based and problem-based learning. This study also found that the teachers still faced difficulties in designing HOTS-based instruction due to their lack of knowledge. The teachers expected an intensive training in order to enhance their understanding towards HOTS-based instruction. This study suggests that Language teaches should emphasize the implementation of HOTS-based instruction in classroom. They also suggested to always improve themselves in understanding the concept of HOTS-based instruction and the importance of implementing it in EFL classroom.

\section{REFERENCES}

Afifah, I. R. N., \& Retnawati, H. (2019). Is it difficult to teach higher order thinking 
skills? Journal of Physics: Conference Series, 1320(1). https://doi.org/10.1088/1742-6596/1320/1/012098

Ahmad, D. (2014). Understanding the 2013 curriculum of English teaching through the teachers' and policymakers' perspectives. International Journal of Enhanced Research in Educational Development (IJERED), 2(4), 6-15.

Andini, S. N. (2017). Teachers' Perception, Knowledge and Behaviour of Higher Order Thinking Skills. ETERNAL (English, Teaching, Learning and Research Journal), 8(1), 20-33.

Assaly, I. R., \& Smadi, O. M. (2015). Using Bloom 's Taxonomy to Evaluate the Cognitive Levels of Master Class Textbook's Questions. English Language Teaching, 8(5), 100-110. https://doi.org/https://doi.org/10.5539/elt.v8n5p100

Bahrudin, D. V. Y., Soleh, M., \& Mukamilah, S. (2020). The Improvement of Students Speaking Skill by Using High Order Thinking Skills (HOTS) Method at MA. Al-Huda Sumber Nangka Desa Duko Timur Kecamatan Larangan Kabupaten Pamekasan. SELL Journal, 5(1), 47-57.

Brookhart, S. M. (2010). How to assess higher-order thinking skills in your classroom.

Duncan, A. (2009). Statement from US Secretary of Education Arne Duncan on results of NAEP Arts 2008 assessment.

Ginting, A. A., \& Kuswandono, P. (2020). Challenges Faced by English Teachers: Implementation of Higher Order Thinking Skills (HOTS) in Designing Assignments in East Indonesia. Pedagogy: Journal of English Language Teaching, 8(1), 13. https://doi.org/10.32332/pedagogy.v8i1.1688

Hashim, A. T., Osman, R., Arifin, A., Abdullah, N., \& Noh, N. M. (2015). Teachers' Perception on Higher Order Thinking Skills as an Innovation and its Implementation in History Teaching. Australian Journal of Basic and Applied Sciences, October, 215-221.

Kurniawati, T. (2019). Improving Students' Higher Order-thinking Skills Through Problem-based Learning in Introduction to Microeconomics Course. KnE Social Sciences, 3(11), 9. https://doi.org/10.18502/kss.v3i11.3995

Kusumastuti, I., Fauziati, E., \& Marmanto, S. (2019). Challenged for Higher-Order Thinking Skill Implementation: Reports From EFL Classroom Teachers. International Journal of Language Teaching and Education, 3(2), 108-117. https://doi.org/10.22437/ijolte.v3i2.7579

Miles, B., Huberman, M., \& Saldana, J. (2014). Qualitative Data Analysis: A Methods Sourcebook. SAGE Pub.

Nachiappan, S., Damahuri, A. A., Ganaprakasam, C., \& Suffian, S. (2018). Application of Higher Order Thinking Skills (Hots) in Teaching and Learning Process in Islamic Education. Advanced Science Letters, 24(7), 5326-5329. https://doi.org/10.1166/asl.2018.11727

Pulungan, M., Toybah, T., \& Suganda, V. A. (2021). Development of HOTS-based 2013 Curriculum Assessment Instruments in Elementary School. Journal of Teaching and Learning in Elementary Education (Jtlee), 4(1), 50. https://doi.org/10.33578/jtlee.v4i1.7858

Seman, S. C., Yusoff, W. M. W., \& Embong, R. (2017). Teachers Challenges in Teaching and Learning for Higher Order Thinking Skills (HOTS) in Primary School. International Journal of Asian Social Science, 7(7), 534-545. https://doi.org/10.18488/journal.1.2017.77.534.545

Suherman, Prananda, M. R., Proboningrum, D. I., Pratama, E. R., Laksono, P., \& Amiruddin. (2020). Improving Higher Order Thinking Skills (HOTS) with 
Project Based Learning (PjBL) Model Assisted by Geogebra. Journal of Physics: Conference Series, 1467(1). https://doi.org/10.1088/17426596/1467/1/012027

Tyas, M. A., Nurkamto, J., Marmanto, S., \& Laksani, H. (2019). Developing Higher Order Thinking Skills (HOTS) - Based Questions: Indonesian EFL Teachers' Challenges. The 2nd International Conference on Future of Education, October, 52-63. https://doi.org/10.17501/26307413.2019.2106

Warmadewi, P. S., Agustini, D. A. E., \& Wedhanti, N. K. (2019). Analysis of Learning Higher Order Thinking Skill (HOTS) Toward English Subject. Jurnal Penelitian Dan Pengembangan Sains Dan Humaniora, 3(2), 134. https://doi.org/10.23887/jppsh.v3i2.21278

Yee, H. M., Lai, S. C., Tee, K. T., \& Mohammad, M. M. (2016). The role of higherorder thinking skills in green skin development. Matec Web Conferences, 15. https://doi.org/10.1051/matecconf/20167005001 